\title{
ASPEK LEGALITAS PEDAGANG KAKI LIMA DI KAWASAN WISATA MALIOBORO
}

\section{LEGALITY ASPECTS STREET VENDORS IN MALIOBORO TOURISM AREA}

\author{
Novarisa Permatasari \\ Program Studi Magister Ilmu Hukum, Universitas Muhammadiyah Yogyakarta \\ novarisapermatasari@yahoo.com
}

\begin{abstract}
Abstrak
Tujuan penelitian untuk mengetahui aspek legalitas pedagang kaki lima di kawasan wisata malioboro dan menganalisis sanksi hukum yang berlaku.bagi pelanggar aturan guna tata kelola kawasan yang baik. Para pedagang menjalankan usahanya untuk menunjang perekonomian dalam memenuhi kebutuhannya sehari-hari, namun perlu adanya perwujudan penataan fungsi tata ruang kawasan yang memperhatikan segala aspek secara optimal. Pemerintah Kota Yogyakarta membuat kebijakan dalam hal penataan pedagang kaki lima agar terwujud tata ruang yang baik di wilayah kawasan Malioboro. Metode pengumpulan data dalam penelitian yaitu yuridis normatif dengan meneliti data sekunder. Hasil penelitian disimpulkan bahwa pedagang kaki lima di Kawasan Malioboro dapat diakui jika telah memiliki Surat Izin Penggunaan Lokasi dan memiliki Kartu Identitas berdasarkan lokasi serta ketentuan jenis barang. Larangan bagi pedagang kaki lima yang berdagang di Kawasan Malioboro telah diatur dalam Peraturan Walikota Yogyakarta dan Peraturan Daerah Kota Yogyakarta. Pelanggar aturan dapat dikenai sanksi pidana dan sanksi administrasi sebagaimana yang tercantum dalam peraturan tersebut.
\end{abstract}

\section{Kata Kunci : Legalitas, Pedagang Kaki Lima, Malioboro}

\begin{abstract}
The purpose of the research to determine the legality aspects of street vendors in the Malioboro tourist area and to analyze the applicable legal sanctions for violators of the rules for good area governance. Street vendors carry out their business to support the economy in fulfilling their daily needs, but there is a need for the realization of an arrangement of regional spatial functions that takes into account all aspects optimally. The Yogyakarta City Government has made a policy in terms of structuring street vendors in order to create a good spatial plan in the Malioboro area. The data collection method in this research is juridical normative by examining secondary data. The results of the study concluded that the street vendors in the Malioboro area can be recognized if they already have a Location Use Permit and have an Identity Card based on the location and provisions on the type of goods. The prohibition for street vendors trading in the Malioboro area is regulated in a Yogyakarta
\end{abstract}


Mayor Regulation and a Yogyakarta City Regional Regulation. Violators of the rules can be subject to criminal sanctions and administrative sanctions as stated in the regulation.

Keywords : Legality, Street Vendors, Malioboro

\section{A. Pendahuluan}

Kota Yogyakarta merupakan ibukota Daerah Istimewa Yogyakarta (DIY) dan menjadi salah satu kota terbesar di Indonesia dan kota terbesar kempat di wilayah Pulau Jawa bagian selatan setelah Bandung, Malang, dan Surakarta menurut jumlah penduduk. Para wisatawan pendatang juga banyak ditemui di kota ini, dimulai dari berbagai daerah bahkan mancanegara. Hal ini disebabkan banyaknya objek wisata menarik yang ada di kota Yogyakarta ini salah satunya di Kawasan Malioboro.

Sebagaimana yang tercantum dalam Pasal 68 huruf d Peraturan Daerah Istimewa Yogyakarta Nomor 5 Tahun 2019 tentang Rencana Tata Ruang Wilayah Daerah Istimewa Yogyakarta Tahun 2019 - 2039 meyebutkan bahwa Keraton-Malioboro dan sekitarnya sebagai kawasan wisata budaya, wisata pendidikan, wisata belanja, kampung wisata, dan kuliner. ${ }^{1}$

\footnotetext{
${ }^{1}$ Pasal 68 huruf d Peraturan Daerah Istimewa Yogyakarta Nomor 5 Tahun 2019 tentang Rencana Tata Ruang Wilayah Daerah Istimewa Yogyakarta Tahun 2019 - 2039
}

Kawasan Wisata Malioboro sangat terkenal dengan adanya pedagang kaki lima yang menjajakan kerajinan khas Jogja dan warung-warung lesehan di malam hari yang menjual makanan gudeg Jogja serta terkenal sebagai tempat berkumpulnya para seniman yang sering mengekpresikan kemampuan mereka seperti bermain musik, melukis, hapening art, pantomim, dan lain-lain di sepanjang jalan ini. $^{2}$ Adanya Pedagang Kaki Lima (selanjutnya digunakan istilah PKL) disana sudah menjadi ciri khas tersendiri bagi kawasan wisata Malioboro yang dapat menarik wisatawan asing untuk datang.

Pedagang Kaki Lima yang istilah lainnya adalah pedagang informal, menjajakan berbagai barang dagangannya dengan membuka lapak di sepanjang jalur trotoar di depan pertokoan yang dipilih mereka sebagai lokasi strategis. Padahal berdasarkan fungsi utamanya, trotoar merupakan bagian dari jalan yang diperuntukkan bagi pejalan kaki. Kondisi

\footnotetext{
2 “Jalan Malioboro" Open Dictionary Wikipedia, (https://id.wikipedia.org/wiki/Jalan Malioboro _diakses tanggal 24 Januari 2021)
} 
demikian menjadikan trotoar sebagai kawasan ruang publik menjadi hilang fungsinya serta mengesampingkan fungsi tata kota yang telah dibuat sebelumnya.

Keberadaan para PKL tersebut menjalankan usahanya untuk menunjang perekonomian dalam memenuhi kebutuhannya sehari-hari, akan tetapi di sisi lain perlu adanya perwujudan penataan fungsi tata ruang kota yang memperhatikan segala aspek secara optimal. PKL seharusnya tetap menjalankan usaha dengan tidak menggangu optimalisasi fungsi tata ruang yang ada.

Pasal 18 ayat (6) UUD 1945 yang menyatakan bahwa pemerintah daerah berhak menetapkan peraturan daerah dan peraturan-peraturan lain untuk melaksanakan otonomi daerah dan tugas pembantuan. ${ }^{3}$ Maka dengan ini, sistem hukum nasional memberikan kewenangan atributif kepada daerah untuk menetapkan Perda dan peraturan daerah lainnya, dan Perda diharapkan dapat mendukung secara sinergis program-program Pemerintah di daerah.

Pemanfaatan ruang publik sebagai lokasi berdagang oleh Pedagang Kaki Lima diatur dalam Pasal 28 huruf c Undang-Undang Nomor 26 Tahun 2007

\footnotetext{
${ }^{3}$ Pasal 18 ayat (6) UUD 1945
}

tentang Penataan Ruang yang menjelaskan mengenai sarana jaringan pejalan kaki yang juga berfungsi untuk pelayanan sosial ekonomi, meskipun di dalam pasal tesebut tidak secara eksplisit menyebut kata 'trotoar'. Pasal tersebut berbunyi:

“ rencana penyediaan dan pemanfaatan prasarana dan sarana jaringan pejalan kaki, angkutan umum, kegiatan sektor informal, dan ruang evakuasi bencana, yang dibutuhkan untuk menjalankan fungsi wilayah kota sebagai pusat pelayanan sosial ekonomi dan pusat pertumbuhan wilayah. “4

Menurut UU Nomor 26 Tahun 2007 tersebut pemerintah daerah kota Yogyakarta memiliki kewenangan dalam Penataan Pedagang Kaki Lima di Kawasan Wisata Malioboro. Kebijakan yang dibuat oleh Pemerintah Kota Yogyakarta dalam hal Penataan Pedagang Kaki Lima ini untuk mewujudkan tata ruang yang baik di wilayah kawasan Malioboro.

Berdasarkan latar belakang yang telah diuraikan maka dirumuskan suatu permasalahan yakni aspek apa saja yang dapat menentukan legalitas Pedagang Kaki Lima di Kawasan Wisata Malioboro guna tata kelola kawasan yang baik dan bentuk sanksi hukum terhadap PKL yang

\footnotetext{
${ }^{4}$ Pasal 28 huruf c Undang-Undang Nomor 26 Tahun 2007 tentang Penataan Ruang
} 
melanggar aturan yang berlaku kawasan wisata Maliboro.

\section{B. Metode Penelitian}

Jenis penelitian yang digunakan merupakan penelitian yuridis normatif dengan meneliti bahan pustaka atau data sekunder. ${ }^{5}$

Bahan hukum primer yang digunakan meliputi :

a) Undang-undang Dasar Negara Republik Indonesia Tahun 1945.

b) Undang-Undang Nomor 26 Tahun 2007 tentang Penataan Ruang.

c) Peraturan Daerah Istimewa Yogyakarta Nomor 5 Tahun 2019 tentang Rencana Tata Ruang Wilayah Daerah Istimewa Yogyakarta Tahun $2019-2039$

d) Peraturan Daerah Kota Yogyakarta Nomor 26 Tahun 2002 tentang Penataan Pedagang Kaki Lima.

e) Peraturan Walikota Yogyakarta Nomor 37 Tahun 2010 tentang Penataan Pedagang Kakilima

Kawasan Khusus Malioboro - A. Yani.

Metode analisis data penelitian ini yaitu menggunakan deskriptif analitis

5 Soerjono Soekanto \& Sri Mamudji, "Penelitian Hukum Normatif (Suatu Tinjauan Singkat)", (Jakarta: Rajawali Pers, 2001), HIm. 13-14 yang menggambarkan tentang peraturan yang berlaku. ${ }^{6}$

\section{Pembahasan}

Dalam mewujudkan pembangunan yang berkelanjutan, dilakukan upaya penataan ruang atau wilayah. Penataan wilayah menyangkut seluruh aspek kehidupan sehingga masyarakat perlu mendapat akses dalam proses perencanaan. Proses perencanaan tersebut diikuti oleh pemanfaatan ruang, dan pengendalian pemanfaatan ruang. Salah satu pengaruh aspek penataan ruang yaitu dari aspek hukum. Aspek hukum memberikan justifikasi dari suatu proses pembangunan. Dengan kata lain produk pembangunan akan berdampak pada produk hukum yang ada serta dimungkinkan dilakukan perubahan-perubahannya. Persoalan hukum menjadi sangat penting ketika terjadi konflik, baik konflik kepentingan, konflik antar pengguna dan lainnya. ${ }^{7}$ Persoalan hukum tersebut dapat dicontohkan dalam suatu aspek legalitas.

Menurut Kamus Besar Bahasa Indonesia (KBBI) legalitas merupakan

6 Bambang Sunggono, Metode Penelitian Hukum, Jakarta, PT Raja Grafindo Persada, 2002, hlm.36

${ }^{7}$ Arif Zulkifli, "Rencana Tata Ruang Wilayah", https://bangazul.com/rencana-tata-ruangwilayah/, diakses tanggal 19 November, 2019, pukul 15.00 WIB. 
perihal sah atau sering disebut dengan keabsahan. ${ }^{8}$ Legalitas adalah suatu perbuatan yang diakui keberadaannya selama tidak ada ketentuan yang mengatur atau perbuatan yang sesuai dengan peraturan perundang-undangan atau hukum yang berlaku. Dalam pemberlakuan legalitas memiliki dasar penunjang yang disebut dengan asas legalitas.

Asas legalitas adalah suatu jaminan dasar bagi kebebasan individu dengan memberi batas aktivitas apa yang dilarang secara tepat dan jelas. Asas ini juga melindungi dari penyalahgunaan wewenang hakim, menjamin keamanan individu dengan informasi yang boleh dan dilarang dan setiap orang harus diberi peringatan sebelumnya tentang perbuatanperbuatan ilegal dan hukumannya. ${ }^{9}$

\section{Legalitas Pedagang Kakilima di} Kawasan Wisata Malioboro Guna Tata Kelola Kawasan yang Baik

Pedagang Kaki Lima lebih dikenal dengan sebutan PKL sudah banyak terdapat hampir disetiap kota maupun desa, salah satunya di Kota Yogyakarta. Pasal 1 huruf d Peraturan Daerah Kota

\footnotetext{
8 Kamus Besar Bahasa Indonesia. [Online] (https://kbbi.web.id/legalitas, diakses tanggal 19 November, 2019, pukul 12.30 WIB.

9 "Asas Legalitas dalam Hukum Islam", (https://www.referensimakalah.com/2012/12/ asas-legalitas-dalam-hukum-islam.html, diakses tanggal 19 November, 2019, pukul 13.30 WIB.
}

Yogyakarta Nomor 26 Tahun 2002 tentang Penataan Pedagang Kaki Lima menyebutkan bahwa :

“ Pedagang kaki lima adalah penjual barang dan atau jasa yang secara perorangan berusaha dalam kegiatan ekonomi yang menggunakan daerah milik jalan atau fasilitas umum dan bersifat sementara/tidak menetap dengan menggunakan peralatan bergerak maupun tidak bergerak. " 10

Salah satu contoh Pedagang Kaki Lima yang beroperasi di Kota Yogyakarta berada di kawasan Malioboro. Pedagang menjual makanan, minuman, pakaian, sandal, tas, cindera mata, makanan, oleholeh (kering), buah-buahan dan sejenisnya. Tumbuhnya PKL di sepanjang jalan Malioboro dikarenakan kawasan tersebut memiliki nilai komersial yang letaknya berdekatan dalam kawasan wisata lainnya, hal tersebut menjadi suatu daya tarik yang kuat untuk dikunjungi oleh wisatawan.

PKL menjadi salah satu faktor meningkatnya akumulasi pengunjung karena keanekaragaman yang disuguhkan memiliki daya tarik tersendiri. Hal tersebut berdampak pada meningkatnya jumlah pengunjung. Bernilai positif juga terhadap pendapatan masyarakat Kota Yogyakarta yang menggantungkan hidupnya sebagai PKL. Perkembangan PKL yang sudah ada

10 Pasal 1 huruf d Peraturan Daerah Kota Yogyakarta Nomor 26 Tahun 2002 tentang Penataan Pedagang Kaki Lima 
pada lokasi tersebut, keberadaannya tetap diperbolehkan, hanya perlu adanya peraturan penataannya agar tidak menimbulkan gangguan dan pelanggaran bagi pedagang, pengunjung, pejalan kaki maupun pengendara. Dikarenakan banyak PKL yang 'waton manggon' (asal menempati) dengan alasan tidak ada lagi yang dapat dilakukan untuk mencari penghidupan. Mereka tidak tertib, melanggar peraturan yang berlaku, dan tidak berwawasan lingkungan dalam berdagang. ${ }^{11}$

Permasalahan PKL sendiri telah diatur dalam peraturan yang berlaku di Pemerintahan Daerah Yogyakarta sesuai dengan pelaksanaan otonomi daerah sebagaimana dicantumkan dalam UndangUndang Dasar Negara Republik Indonesia Tahun 1945 bahwasanya Pemerintahan daerah Provinsi, Daerah Kabupaten, dan Kota mengatur dan mengurus sendiri urusan pemerintahan menurut asas otonomi dan tugas pembantuan. ${ }^{12}$

Terkait kebijakan penataan Pedagang Kaki Lima di Kawasan Wisata Malioboro diatur dan diimplementasikan sesuai

11 Budi Sutrisno, dkk., "Pola Penataan Pedagang Kaki Lima (PKL) Di Kota Surakarta Berdasar Paduan Kepentingan PKL, Warga Masyarakat, dan Pemerintah Kota" ( Jurnal Penelitian Humaniora, Vol. 8, No. 2, 2007), Hal. 167.

12 Undang-Undang Dasar Negara Republik Indonesia Tahun 1945. Pasal 18 Ayat (2)
Peraturan Daerah Kota Yogyakarta Nomor

26 Tahun 2002 tentang Penataan Pedagang Kaki Lima. Peraturan Daerah tersebut diturunkan dalam peraturan pelaksanaan yaitu Peraturan Walikota Yogyakarta Nomor 37 Tahun 2010 tentang Penataan Pedagang Kakilima Kawasan Khusus Malioboro - A. Yani dimana aturan tersebut menerapkan prinsip kesejahteraan manusia.

Peraturan penataan pedagang kakilima pada kawasan Malioboro ditentukan berdasarkan lokasi, ketentuan jenis dagang hingga perizinan. Pasal 2 Peraturan Walikota Yogyakarta Nomor 37 Tahun 2010 tentang Penataan PKL Kawasan Khusus Malioboro - A. Yani menentukan lokasi-lokasi yang dapat ditempati sebagai berikut :

(1). trotoar sisi barat jalan Malioboro dan jalan A. Yani (persimpangan jalan Malioboro dan jalan Pasar Kembang sampai dengan simpang tiga jalan Reksobayan);

(2) trotoar sisi timur jalan Malioboro dan jalan A. Yani (depan Hotel Garuda sampai depan Pasar Sore Malioboro) kecuali paving sisi timur yang termasuk dalam kawasan Pasar Beringharjo;

(3) sirip jalan Malioboro - A. Yani adalah trotoar jalan Pajeksan sisi utara dan selatan, jalan Suryatmajan sisi selatan dan jalan Reksobayan sisi utara 


$$
\begin{aligned}
& \text { (selatan Gereja } \\
& \text { Yogyakarta). }
\end{aligned}
$$

Penataan lokasi PKL sebagaimana yang dimaksud dalam Pasal 2 ayat (1) dan ayat (2) ditetapkan dengan Surat Keputusan Kepala Dinas Pariwisata dan Kebudayaan dan di lokasi tersebut melarang penambahan jumlah PKL. Pada pasal 2 ayat (3) penataan lokasinya ditentukan dengan Keputusan Camat setempat dan di sirip jalan tersebut terdapat beberapa jalan yang dilarang untuk ditambah jumlahnya, yaitu jalan Suryatmajan, jalan Pajeksan dan jalan Reksobayan.

Ketentuan pasal diatas, dapat disimpulkan bahwa PKL tersebut tidak diperbolehkan untuk berdagang/berusaha di wilayah selain yang disebutkan. Peraturan Walikota Yogyakarta Nomor 37 Tahun 2010 tentang Penataan PKL Kawasan Khusus Malioboro-A.Yani mengatur mengenai kawasan PKL berdasarkan jenis dagangan dan aturan dalam mengontrol keberadaan PKL agar lebih tertib dan tertata, yaitu dengan mewajibkan PKL memiliki surat izin dan kartu identitas sebagaimana yang tercantum dalam Pasal 7 yang menyebutkan bahwa:

\footnotetext{
13 Pasal 2 Peraturan Walikota Yogyakarta Nomor 37 Tahun 2010 tentang Penataan Pedagang Kakilima Kawasan Khusus Malioboro - A. Yani.
}

(1).PKL wajib memiliki Surat Izin Penggunaan Lokasi Pedagang Kaki Lima dan Kartu Identitas Pedagang Kaki Lima.

(2).Pejabat yang ditunjuk untuk menerbitkan Surat Izin Penggunaan Lokasi Pedagang Kakilima dan Kartu Identitas Pedagang Kaki Lima sebagaimana dimaksud pada ayat (1) adalah Kepala Dinas Pariwisata dan Kebudayaan atas nama Walikota untuk pedagang kakilima Kawasan Khusus Malioboro - A. Yani yang berada di lokasi sebagaimana dimaksud dalam Pasal 2 ayat (1) dan (2).

(3).Pejabat yang ditunjuk untuk menerbitkan Surat Izin Penggunaan Lokasi Pedagang Kakilima dan Kartu Identitas Pedagang Kakilima sebagaimana dimaksud pada ayat (1) adalah Camat atas nama Walikota untuk pedagang kakilima Kawasan Khusus Malioboro - A. Yani yang berada di lokasi sebagaimana dimaksud dalam Pasal 2 ayat (3) sesuai dengan wilayah kerjanya.

(4). Masa berlaku Surat Izin Penggunaan Lokasi Pedagang Kakilima dan Kartu Identitas Pedagang Kakilima adalah 2 (dua) tahun."14

Sebagaimana yang disebutkan dalam ayat (4) diatas, masa berlaku surat izin penggunaan Lokasi PKL dan Kartu Identitas selama dua tahun sehingga PKL

\footnotetext{
14 Pasal 7 Peraturan Walikota Yogyakarta Nomor 37 Tahun 2010 tentang Penataan Pedagang Kakilima Kawasan Khusus Malioboro - A. Yani.
} 
harus melapor dan melakukan perpanjangan kepada Dinas Pariwisata dan Kebudayaan maupun kecamatan setempat. Mengenai tata cara pengajuan Surat Izin Penggunaan Lokasi Pedagang Kakilima dan Kartu Identitas Pedagang Kaki Lima yaitu dengan mengajukan formulir permohonan yang telah disediakan yang dilampirkan persyaratan yang telah ditetapkan. Adapun persyaratannya tertulis dalam Pasal 11 Peraturan Walikota Yogyakarta Nomor 37 Tahun 2010 sebagai berikut.

a. fotokopi Kartu Tanda Penduduk (KTP) Kota/ Kabupaten di Propinsi Daerah Istimewa Yogyakarta;

b. pas photo terbaru, hitam putih ukuran $2 \times 3 \mathrm{~cm}$, sebanyak 5 lembar;

c. surat pernyataan belum memiliki tempat usaha;

d. surat pernyataan kesanggupan untuk melakukan bongkar pasang peralatan dan dagangan, menyediakan tempat sampah, menjaga ketertiban, keamanan, kesehatan, kebersihan dan keindahan serta fungsi fasilitas umum;

e. surat pernyataan kesanggupan untuk mengembalikan lokasi usaha apabila Pemerintah Daerah akan mempergunakan untuk kepentingan umum yang lebih luas tanpa syarat apapun;

f. surat pernyataan kesanggupan untuk mengembalikan lokasi usaha kepada Pemerintah Daerah apabila pemilik usaha/ kuasa hak atas bangunan/ tanah yang berbatasan langsung dengan jalan

akan mempergunakannya tanpa syarat apapun;

g. persetujuan dari pemilik usaha/ kuasa hak atas bangunan/ tanah yang berbatasan langsung dengan jalan, apabila berusaha di daerah milik jalan dan atau persil;

h. denah lokasi yang akan diajukan izin;

i. surat pernyataan kesanggupan untuk memasang daftar harga yang dapat diketahui oleh umum khusus bagi pedagang kakilima dengan jenis dagangan makanan dan minuman baik yang menggunakan dasaran atau tidak menggunakan dasaran dan atau menyediakan tempat untuk makan/ minum termasuk lesehan;

j. melampirkan Sertifikat Laik Sehat yang masih berlaku dari Dinas Kesehatan Kota Yogyakarta bagi pedagang kakilima dengan jenis dagangan makanan dan minuman-kecuali makanan dan minuman kemasan yang terdaftar di Badan Pengawas Obat dan Makanan (BPOM)."15

Surat izin penggunaan lokasi PKL dan kartu identitas PKL tidak berlaku dengan ketentuan sebagaimana disebutkan dalam Pasal 10 yang menegaskan bahwa :

"Surat Izin Penggunaan Lokasi PKL dan Kartu Identitas PKL dinyatakan tidak berlaku apabila : a) pindah tempat usaha; b) terjadi pergantian pemilik atau dipindah tangankan; c) habis masa berlakunya; d) terjadi pergantian golongan jenis tempat usaha; e) terjadi pergantian jenis dagangan; f)

\footnotetext{
15 Pasal 11 Peraturan Walikota Yogyakarta Nomor 37 Tahun 2010 tentang Penataan Pedagang Kakilima Kawasan Khusus Malioboro - A. Yani
} 
terjadi perubahan fungsi daerah milik jalan dan atau persil; g) pemegang surat izin meninggal dunia." 16

Berdasarkan ketentuan dan aturanaturan diatas, legalitas PKL di Kawasan Wisata Malioboro dapat diakui jika telah memiliki Surat Izin Penggunaan Lokasi PKL dan Kartu Identitas PKL sesuai dengan ketentuan jenis dagangan yang diterbitkan oleh kecamatan setempat maupun dinas terkait sebagai tanda bukti pendaftaran usaha PKL sekaligus sebagai alat kendali untuk pemberdayaan dan pengembangan usaha PKL di Kawasan Wisata Malioboro. Slamet Santoso sebagai Ketua Umum Paguyuban Pedagang Kaki Lima Malioboro hingga Ahmad Yani (Pemalni) mengatakan bahwa jumlah PKL yang tercatat sebagai anggota Pemalni mencapai 444 orang. Seluruhnya sudah memiliki izin, namun masih ada PKL yang belum masuk basis data, berjumlah enam pedagang. ${ }^{17}$

Berdasarkan pernyataan tersebut dapat dikatakan bahwa masih ada Pedagang

\footnotetext{
16 Pasal 10 Peraturan Walikota Yogyakarta Nomor 37 Tahun 2010 tentang Penataan Pedagang Kakilima Kawasan Khusus Malioboro - A. Yani

17 Nur Aini, "Yogyakarta akan Tata PKL di Sisi Barat Jalan Malioboro", https://nasional.republika.co.id/berita/puvrnp38 2/yogyakarta-akan-tata-pkl-di-sisi-barat-jalanmalioboro, diakses tanggal 24 Januari 2021, pukul 09.15 WIB.
}

Kaki Lima di Kawasan Wisata Malioboro yang statusnya ilegal (tidak memiliki izin) sehingga PKL diwajibkan menaati aturan yang berlaku dengan mengurus izin sebagai tanda bukti legalnya kawasan yang ditempati demi menjaga stabilitas ketertiban tata wilayah kawasan malioboro sesuai dengan harapan pemerintah yang memiliki tujuan tata kelola yang baik guna mendukung kesejahteraan PKL di Kawasan Wisata Malioboro. PKL diharapkan untuk aktif mencari tahu dan memahami aturan yang telah dibuat pemerintah agar tidak timbul permasalahan terhadap ilegalnya lapak yang mereka tempati.

\section{Sanksi Hukum Bagi PKL yang Melanggar Peraturan Daerah yang \\ Berlaku di Kawasan Maliboro}

Persoalan PKL harus sesegera mungkin diselesaikan agar tidak berlarutlarut. Dalam hal ini perlu adanya koordinasi dari pemerintah daerah setempat, para PKL, dan masyarakat sekitar. Koordinasi tersebut diwujudkan dengan adanya sosialisasi yang membahas mengenai penataan ruang yang didasarkan pada karakteristik, daya dukung dan daya tampung lingkungan yang sesuai, sehingga dapat meningkatkan keserasian, keselarasan, dan kesinambungan antar subsistem. Fungsi penataan ruang selain 
berguna menjaga keseimbangan ekologis (seperti banjir, krisis air, dan pemcemaran udara), juga dapat mempengaruhi kesejahteraan masyarakat serta PKL itu sendiri.

Di dalam mewujudkan tata kota yang baik, Pemerintah Kota Yogyakarta membentuk tim khusus menangani PKL, yang terdiri dari Dinas Ketertiban, Dinas Perindustrian Perdagangan Koperasi dan Pertanian, Dinas Pemukiman Prasarana Wilayah, Dinas Perhubungan, Badan Lingkungan Hidup dan Bagian Tata Pemerintahan. Dalam penataan PKL Kawasan Khusus Malioboro - A. Yani dibentuk tim berdasarkan Keputusan Kepala Dinas Pariwisata dan Kebudayaan. Unsur tim tersebut tercantum dalam Pasal 16 ayat (2) Peraturan Walikota Yogyakarta Nomor 37 Tahun 2010 tentang Penataan Pedagang Kakilima Kawasan Khusus Malioboro-A. Yani yaitu UPT Malioboro, Kecamatan, Kelurahan, LPMK, LPKKM dan Organisasi/Paguyuban Pedagang Kakilima. Mereka memiliki kewenangan dalam penentuan program pemberdayaan dan menentukan langkah yang strategi dalam menata sekaligus menertibkan PKL yang melanggar aturan dan laranganlarangan yang telah ditetapkan oleh peraturan pemerintah.

Ditinjau dari aspek legalitasnya, selain diwajibkan memiliki Surat Izin
Penggunaan Lokasi PKL dan Kartu Identitas PKL, terdapat larangan bagi PKL yang berdagang di kawasan Malioboro sebagaimana yang diatur dalam Pasal 18 Peraturan Walikota Yogyakarta Nomor 37 tahun 2010 tentang Penataan Pedagang Kaki Lima Kawasan Khusus Malioboro A. Yani yaitu:

"Pedagang Kakilima Kawasan Khusus Malioboro - A. Yani dilarang :

a. melakukan kegiatan usaha selalin di lokasi yang telah diizinkan;

b. menjual belikan, menyewakan, dan atau memindahtangankan lokasi usaha kepada pihak manapun;

c. menempatkan barang dagangan melebihi garis batas yang telah ditentukan (keluasan dan ketinggian);

d. menempatkan peralatan/kotakkotak selain yang dipergunakan untuk berjualan, sepeda, sepeda motor dan sejenisnya di sekitar lokasi berjualan, pada badan jalan/jalur lambat, trotoar, devider, taman, lampu taman, dan kursi taman;

e. mengkaitkan dan mengikatkan tali tenda dan peralatan kegiatan usaha pada pohon, pagar, dan fasilitas umum lainnya;

f. mempergunakan alat penutup plastik/kain sehingga kelihatan kumuh, tidak rapi dan mengganggu keindahan lingkungan khusus untuk pedagang kakilima di depan pertokoan;

g. berjualan pada badan jalan, jalur lambat, dan di tempat parkir; 
h. meninggalkan barang-barang, peralatan maupun dagangan setelah selesai berjualan;

i. berjualan di Jalan Pasar Kembang, Jalan Abubakar Ali (utara Hotel Garuda), Jalan Sosrowijayan, Jalan Perwakilan, Jalan Dagen, Jalan Beskalan dan Jalan Ketandan."18

Dengan adanya aturan dan larangan yang telah ditetapkan pemerintah, maka terdapat pula sanksi pidana dan sanksi administrasi yang dapat dikenakan bagi PKL yang melanggar. Peraturan Walikota Nomor 37 Tahun 2010 tentang Penataan Pedagang Kaki Lima Kawasan Khusus Malioboro - A. Yani ini merupakan penerapan dari Peraturan Daerah Kota Yogyakarta Nomor 26 Tahun 2002 tentang Penataan Pedagang Kaki Lima. Sehingga sanksi yang dapat dikenakan tercantum dalam Peraturan Daerah tersebut.

Sanksi pidana dalam Peraturan Daerah Kota Yogyakarta Nomor 26 Tahun 2002 tentang Penataan Pedagang Kaki Lima diatur dalam Bab VIII ketentuan pidana Pasal 12 yaitu :

1. Pelanggaran terhadap ketentuan - ketentuan sebagaimana diatur dalam Pasal 3 ayat (1) yang mengatakan bahwa setiap PKL yang akan melakukan kegiatan usaha dan menggunakan lokasi sebagaimana dimaksud dalam

\footnotetext{
18 Pasal 18 Peraturan Walikota Yogyakarta Nomor 37 tahun 2010 tentang Penataan Pedagang Kaki Lima Kawasan Khusus Malioboro - A. Yani.
}

Pasal 2 ayat (2) Peraturan Daerah ini, wajib memiliki izin penggunaan lokasi dan kartu identitas dari Walikota atau Pejabat yang ditunjuk., Pasal 6 dan pasal 8 Peraturan Daerah ini, diancam dengan pidana kurungan paling lama 3 (tiga) bulan atau denda paling banyak Rp. 2.000.000,- (dua juta rupiah).

2. Tindak pidana sebagaimana dimaksud pada ayat (1) Pasal ini adalah pelanggaran."19

Pada pasal 6 Peraturan Daerah Kota Yogyakarta Nomor 26 Tahun 2002 tentang penataan PKL menjelaskan tentang kewajiban yang harus dipatuhi yaitu berupa izin penggunaan lokasi dan kartu identitas, mematuhi ketentuan peraturan perundang-undangan yang berlaku, mengemas dan memindahkan peralatan dari lokasi setelah selesai menjalankan usahanya, memberi akses jalan ke bangunan /tanah yang berbatasan langsung dengan jalan. Kemudian, dalam pasal 8 terdapat 7 sub pasal yang berisi tentang larangan memperjual-belikan lokasi berjualan pada pihak manapun, melakukan kegiatan usaha di tempat yang telah dilarang seperti Monumen Serangan Umum 1 Maret, Gedung Agung, Taman Makam Pahlawan Kusumanegara dan juga dilarang melakukan kegiatan yang dapat

\footnotetext{
19 Pasal 12 Peraturan Daerah Kota Yogyakarta Nomor 26 Tahun 2002 tentang Penataan Pedagang Kaki Lima.
} 
merusak keindahan dan kebersihan, menggunakan lahan melebihi ketentuan yang diberikan, dan melakukan kegiatan usaha yang dilarang oleh peraturan yang berlaku.

Selain sanksi pidana, PKL yang melanggar aturan dan larangan juga dapat dikenakan sanksi administrasi sebagaimana Pasal 15 Peraturan Daerah Kota Yogyakarta Nomor 26 Tahun 2002 tentang penataan pedagang Kaki Lima yaitu :

(1). Selain diancam pidana sebagaimana dimaksud dalam Pasal 12 ayat (1) Peraturan Daerah ini, terhadap pelanggaran ketentuan Pasal 3 ayat (1), Pasal 6 dan Pasal 8 Peraturan Daerah ini, Walikota atau pejabat yang ditunjuk berwenang untuk:

a) Mencabut izin sebagaimana dimaksud dalam Pasal 3 ayat (1) Peraturan Daerah ini;

b) Menutup usaha pedagang kakilima yang tidak mempunyai izin dan atau menempati lokasi selain yang telah diizinkan.

(2). Walikota atau pejabat yang ditunjuk selain mempunyai kewenangan sebagaimana dimaksud pada ayat (1) Pasal ini, juga mempunyai kewenangan untuk mencabut izin penggunaan lokasi sebagaimana dimaksud dalam Pasal 3 ayat (1) Peraturan Daerah ini, apabila:

a) Lokasi yang dipergunakan oleh pedagang kaki lima digunakan oleh Pemerintah Daerah untuk kepentingan umum yang lebih luas; b) 30 (tiga puluh) hari berturutturut lokasi tidak dipergunakan tanpa keterangan yang dapat dipertanggung-jawabkan;

Pedagang kakilima melanggar ketentuan peraturan perundangundangan yang berlaku." 20

Dalam proses penegakan peraturan terhadap pelanggar aturan, sesuai Peraturan Pemerintah daerah kota Yogyakarta nomor 26 tahun 2002 dilakukan melalui dinas ketertiban. Menurut Bapak Budi (Seksi Penegakan Operasional Dinas Satuan Polisi Pamong Praja/Satpol PP) terdapat mekanisme tata urutan bagi PKL yang melanggar yaitu harus ada surat peringatan pertama, surat peringatan kedua, dan surat peringatan ketiga. Jika tidak diindahkan juga, maka tempat dimana PKL berdagang harus dibongkar, kalau tidak dibongkar maka ditindak oleh Dinas Satpol PP. ${ }^{21}$ Bidang Polisi Pamong Praja mempunyai fungsi memelihara pembinaan ketentraman dan ketertiban umum serta menegakkan Peraturan Daerah secara non-yustisi.

20 Pasal 15 Peraturan Daerah Kota Yogyakarta Nomor 26 Tahun 2002 tentang Penataan Pedagang Kaki Lima

21 M Bagaskara Mustijuan, Penerapan Perda Kota Yogyakarta No. 26 Tahun 2002 tentang Penataan Pedagang Kaki Lima di Yogyakarta (Studi Kasus: Stasiun Lempuyangan), Skripsi Hukum, Fakultas Hukum. (Yogyakarta: UMY, 2018. Repository UMY). HIm. 48. 
Apabila pedagang tidak dapat

malioboro sesuai dengan harapan menunjukkan surat sebagai bukti telah menyelesaikan administrasi perijinan atau kembali melakukan tindak pelanggaran, maka dinas ketertiban melalui satuan polisi pamong praja akan melakukan penindakan secara tegas dengan cara menyita dan melimpahkan proses hukum kepada pengadilan.

Berdasarkan ketentuan diatas, pemerintah dalam menyikapi adanya PKL di Kawasan Wisata Malioboro telah mengutamakan penegakan keadilan bagi rakyat dengan menjamin legalitas PKL sesuai izin yang berlaku yaitu dengan adanya Surat Izin Penggunaan Lokasi PKL dan Kartu Identitas PKL serta kepatuhan PKL terhadap ketentuan dan aturan yang ditetapkan. Diharapkan kedepannya tidak ada lagi PKL yang melanggar aturan serta larangan agar terciptanya ketertiban dan tata kelola wilayah yang baik.

\section{Kesimpulan}

Berdasarkan uraian diatas dapat ditarik kesimpulan bahwa legalitas PKL di Kawasan Malioboro dapat diakui jika telah memiliki Surat Izin Penggunaan Lokasi PKL dan Kartu Identitas PKL berdasarkan lokasi serta ketentuan jenis dagang. PKL juga diwajibkan menaati ketentuan dan aturan yang berlaku demi menjaga stabilitas tata wilayah kawasan wisata pemerintah dengan tujuan kesejahteraan bersama sebagaimana yang tercantum Pasal 2, 7 dan 10 Peraturan Walikota Yogyakarta Nomor 37 Tahun 2010 tentang Penataan Pedagang Kakilima Kawasan Khusus Malioboro-A. Yani.

Larangan bagi PKL yang berdagang di Kawasan Malioboro diatur dalam Pasal 18 Peraturan Walikota Yogyakarta Nomor 37 tahun 2010 tentang Penataan Pedagang Kaki Lima Kawasan Khusus Malioboro A. Yani serta Pasal 6 dan 8 Peraturan Daerah Kota Yogyakarta Nomor 26 tahun 2002 tentang Penataan Pedagang Kaki Lima. Berdasarkan peraturan tersebut bahwa PKL di kawasan wisata Malioboro yang melanggar aturan dapat dikenai sanksi pidana Pasal 12 Peraturan Daerah Kota Yogyakarta Nomor 26 Tahun 2002 tentang Penataan Pedagang Kaki Lima yaitu berupa pidana kurungan paling lama 3 (tiga) bulan atau denda paling banyak Rp. 2.000.000,- (dua juta rupiah) dan sanksi administrasi Pasal 15 Peraturan Daerah Kota Yogyakarta Nomor 26 Tahun 2002 tentang Penataan Pedagang Kaki Lima berupa mencabut izin penggunaan lokasi dan menutup usaha pedagang kakilima yang tidak mempunyai izin dan atau menempati lokasi selain yang telah diizinkan. Kewenangan sanksi 
administrasi tersebut diberikan kepada walikota atau camat setempat.

\section{Daftar Pustaka}

\section{Buku}

Bambang Sunggono, Metode Penelitian Hukum, Jakarta : PT Raja Grafindo Persada, 2002.

\section{Karya Ilmiah}

Budi Sutrisno, dkk, Pola Penataan Pedagang Kaki Lima (PKL) Di Kota Surakarta Berdasar Paduan Kepentingan PKL, Warga Masyarakat, dan Pemerintah Kota", Jurnal Penelitian Humaniora, Vol. 8, No. 2, 2007.

M Bagaskara Mustijuan, Penerapan Perda Kota Yogyakarta No. 26 Tahun 2002 tentang Penataan Pedagang Kaki Lima di Yogyakarta (Studi Kasus: Stasiun Lempuyangan), Skripsi Hukum, Fakultas Hukum. Yogyakarta: Repository UMY, 2018.

\section{Peraturan Perundang-Undangan}

Undang-Undang Dasar Negara Republik Indonesia Tahun 1945.

Peraturan Daerah Istimewa Yogyakarta Nomor 5 Tahun 2019 tentang Rencana Tata Ruang Wilayah Daerah Istimewa Yogyakarta Tahun 2019 - 2039.

Peraturan Daerah Kota Yogyakarta Nomor 26 Tahun 2002 tentang Penataan Pedagang Kaki Lima.

Peraturan Walikota Yogyakarta Nomor 37 tahun 2010 tentang Penataan Pedagang Kaki Lima Kawasan Khusus Malioboro - A. Yani.

\section{Website}

Arif Zulkifli. "Rencana Tata Ruang Wilayah",

https://bangazul.com/rencana-tataruang-wilayah/, diakses tanggal 19 November, 2019, pukul 15.00 WIB.

Asas Legalitas dalam Hukum Islam, https://www.referensimakalah.com/ 2012/12/asas-legalitas-dalamhukum-islam.html, diakses tanggal 19 November, 2019, pukul 13.30 WIB.

Kamus Besar Bahasa Indonesia. [Online] (https://kbbi.web.id/legalitas, diakses tanggal 19 November, 2019, pukul 12.30 WIB.

Nur Aini, "Yogyakarta akan Tata PKL di Sisi Barat Jalan Malioboro", https://nasional.republika.co.id/berita/p uvrnp382/yogyakarta-akan-tata-pkldi-sisi-barat-jalan-malioboro, diakses 24 Januari 2021, pukul 09.15 WIB. 